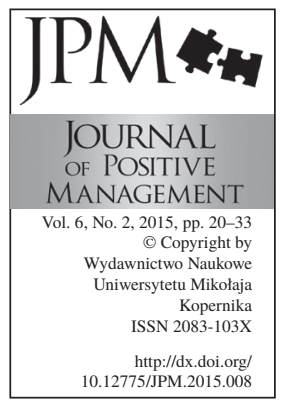

\title{
SUCCESS OF A COMPANY THROUGH VALUE APPROACH
}

\author{
Deniss Š́̌̌eulovs ${ }^{\mathrm{a}}$, Vladimirs Šatrevičs ${ }^{\mathrm{b}}$, Elīna Gaile-Sarkane ${ }^{\mathrm{c}}$ \\ Riga Technical University, \\ Faculty of Engineering Economics and Management, Riga, Latvia \\ ${ }^{a}$ e-mail: deniss.sceulovs@rtu.lv \\ b e-mail: vladimirs.satrevics@rtu.lv \\ ce-mail: elina.gaile-sarkane@rtu.lv
}

\begin{abstract}
The formation of new companies is considered to be one of the most important sources of new workplaces creation. In United States new companies generate half of all new workplaces in the country (SBA, 2012). Therefore, in Latvia it is particularly important to encourage new businesses' formation and development in order to achieve both economic growth and improvements in employment. The purpose of the Research paper is to study the factors that positively influenced the development of enterprises, named as "success factors", creating success factors model affecting entrepreneurial process.

Methodology the theoretical and methodological groundwork of the study is based of scientific and business literature. In the research generally accepted qualitative and quantitative data analysis methods of the economic science were employed, among them, statistical data processing, data grouping, and inductive-deductive data analysis methods. The scientific study employs surveying, observation study method, as well as comparative, and analytical methods, which are used by the authors to compare and analyse facts and assess solutions to specific issues. Microsoft Excel and QDA Miner programs were used for processing and analysing the study results.
\end{abstract}

Findings: paper investigate stakeholders values role in entrepreneurial process during development process. It is also questioned by the authors of the paper why Latvian many start-ups are short-lived? Why in Latvia not so much success stories compared to other countries - for example Estonia, Scandinavia and United States (in proportion to the size of the economy or population). It is noted several possible causes: lack of access to finance to start-up business, quality of education programs, lack of access to infrastructure and other factors.

Keywords: entrepreneur, success factors, development of a company, growth, stakeholders values Paper type: Research paper

\section{Introduction}

The formation of new enterprises is regarded as one of the most important sources of creating new jobs. For instance, US start-ups account for a half of all new jobs 
seven increase the number of employees by $60 \%$, whereas companies that survive in Europe increase the number of employees by about 10\%-20 \% (GEM Report, 2013). The foundation of Latvian and EU economy is formed of micro-, small, and medium enterprises (SME). They account for $98.8 \%$ of all companies (SBA Facts, 2012). SME face various difficulties in starting entrepreneurship and managing to keep it alive. The biggest challenge for SMEs is the limited availability of various resources (financial, human resources, etc.). Furthermore, if compared with the bigger companies, a smaller number of European SMEs achieve innovations. The situation is deteriorated by structural hardships, such as, lack of managerial and technical skills, and at the state level the labour market is still inflexible. These and other factors adversely affect sustainability of companies. At the same time, there are a range of success factors, which contribute to growth of companies and successful entrepreneurship.

The aim of the study is to determine and group the factors, which positively affect development (hereinafter in the study referred to as "success factors") and contribute to sustainable development of companies in Latvia.

The authors justify this choice with the fact that data about companies, which manage to successfully develop are available less frequently than data about "failure factors", i.e. about companies, which have ceased to exist. The determination and analysis of such success factors will help the developers and implementers of various state education and lifelong learning programmes in their work, as well as assist start-ups and existing companies to analyse and pinpoint their strengths. The same applies to other non-entrepreneurship spheres (such as, non-governmental organisations, etc.), where timely attention must be paid to promoting development.

The authors have set forth a thesis to perform the study: irrespective of the sphere and sector of the enterprise's operations and independent of its size (within the context of SMEs), there is a set of factors. The use of these factors promotes successful entrepreneurship and development of the company.

The theoretical and methodological groundwork of the study is formed of scientific articles, monographs, regulatory enactments and researches, conference materials, internet resources, expert opinions published in Latvia and abroad. In the research generally accepted qualitative and quantitative data analysis methods of the economic science were employed, among them, statistical data processing, data grouping, and inductive-deductive data analysis methods. The scientific study employs surveying, observation study method, as well as comparative, and analytical methods, which are used by the authors to compare and analyse facts and assess solutions to specific issues. Microsoft Excel and QDA Miner programs were used for processing and analysing the study results. 
SUCCESS

OF A COMPANY

THROUGH VALUE

Deniss Ščeulovs

Vladimirs Šatrevičs

Elīna Gaile-Sarkane

Table 1.

New and eliminated companies in Latvia, 2002-2013

Source: Register of Enterprises of Latvia.

Table 2.

Economically active statistical units in

Latvia 2009-2012

Source: Central

Statistical Bureau of Latvia 2013.

\section{Latvian entrepreneurship overview}

Overall, an upwards trend can be observed in Latvia as regards the formation of new companies, as shown by statistics about newly registered economic operators for the time period from 2002 until 2013 (Table 1).

\begin{tabular}{cccc}
\hline Year & $\begin{array}{c}\text { Number of all new com- } \\
\text { panies (A) }\end{array}$ & $\begin{array}{c}\text { Number of all } \\
\text { eliminated companies (B) }\end{array}$ & $\begin{array}{c}\text { Balance } \\
\text { (A-B) }\end{array}$ \\
\hline 2002 & 7077 & 3211 & 3866 \\
\hline 2003 & 8473 & 2984 & 5489 \\
\hline 2004 & 11026 & 4842 & 6184 \\
\hline 2005 & 12051 & 8670 & 3381 \\
\hline 2006 & 14724 & 3355 & 11369 \\
\hline 2007 & 15530 & 13746 & 1784 \\
\hline 2008 & 12733 & 5335 & 7398 \\
\hline 2009 & 10964 & 5827 & 5137 \\
\hline 2010 & 15369 & 8938 & 6431 \\
\hline 2011 & 19942 & 4041 & 15901 \\
\hline 2012 & 18574 & 4442 & 14132 \\
\hline 2013 & 18035 & 4300 & 13735 \\
\hline 2014 & 16404 & 6663 & 9741 \\
\hline
\end{tabular}

The rate of growth in the number of start-ups companies is positive (see Table 1), excluding the years of global economic recession, which adversely affected also the Latvian micro and macroeconomic situation. The dynamics of liquidated companies has been uneven, however, over the last few years, a positive trend is observed, namely, the number of liquidated companies is reducing. The authors would like to draw attention to the fact that the table and figures show data about the existing Latvian entrepreneurship forms, therefore, to provide a better outlook, they distinguished between entrepreneurship forms which can bring profits, because according to the laws of the Republic of Latvia, public and nongovernmental organisations are non-profit organisations (Table 2).

\begin{tabular}{lrrrrr}
\hline $\begin{array}{l}\text { Type } \\
\text { of entrepreneurship }\end{array}$ & $\mathbf{2 0 0 9}$ & $\mathbf{2 0 1 0}$ & $\mathbf{2 0 1 1}$ & $\mathbf{2 0 1 2}$ & $\mathbf{2 0 1 3}$ \\
\cline { 2 - 6 } Self-employed persons & 45279 & 49063 & 47878 & 51535 & 50882 \\
\hline Individual merchants & 8242 & 8142 & 8000 & 7657 & 7582 \\
\hline Commercial companies & 63172 & 65629 & 72708 & 79777 & 85407 \\
\hline $\begin{array}{l}\text { Peasant and fishermen } \\
\text { farms }\end{array}$ & 11916 & 13133 & 13192 & 12574 & 11368 \\
\hline Total & 128609 & 135967 & 141778 & 151543 & 155239 \\
\hline
\end{tabular}


Total growth of the number of companies, \% compared to the previous year starting from 2009 is $5.7 \%$ in 2010, $4.3 \%$ in 2011, and $6.9 \%$ in 2012 and decreased in 2013 by $2.4 \%$. In Latvia, similar to the EU, SMEs make up the biggest part in the total number of companies. Micro enterprises make up the biggest part in the group of micro, medium, and small enterprises, and their number keeps increasing with every year (Table 3 ).

\begin{tabular}{|c|c|c|c|c|c|}
\hline \multirow{2}{*}{ Unit by size } & \multicolumn{5}{|l|}{ Year } \\
\hline & 2009 & 2010 & 2011 & 2012 & 2013 \\
\hline Micro & 115939 & 123924 & 129394 & 138841 & 144211 \\
\hline Small & 10254 & 9732 & 9970 & 10448 & 9219 \\
\hline Medium & 2065 & 1956 & 2033 & 2083 & 1476 \\
\hline Large & 351 & 355 & 381 & 400 & 252 \\
\hline Total & 128609 & 135967 & 141778 & 151543 & 155158 \\
\hline
\end{tabular}

The increase in the number of companies in practically all company groups is observed each year, which points to positive growth trends of Latvian economy (Table 4). In 2013 is observed share structure changes.

\begin{tabular}{lrrrrc}
\hline \multirow{2}{*}{ Indicator } & \multicolumn{1}{l}{ Year } & & & & \\
\cline { 2 - 6 } & $\mathbf{2 0 0 9}$ & $\mathbf{2 0 1 0}$ & $\mathbf{2 0 1 1}$ & $\mathbf{2 0 1 2}$ & \multicolumn{1}{c}{$\mathbf{2 0 1 3}$} \\
\hline Net turnover & 36283.2 & 39994.4 & 45491.1 & 51079.2 & 53808.4 \\
\hline Profit or loss before taxes & -807.3 & 306.2 & 1286.7 & 1476.0 & 1682.3 \\
\hline Profit or loss after taxes & -1072.8 & -4.8 & 957.7 & 1078.7 & 1272.6 \\
\hline
\end{tabular}

Over the last four years, an annual increase in turnover of companies has been observed (see Table 4), furthermore, in the last two years, companies have generally closed a year with positive profits, which also points to economic growth.

Global Entrepreneurship Monitor (GEM) 2012/2013, indicates that, while Latvia has achieved a high early stage entrepreneurship rate, there is still potential for improvement. A gap exists between entrepreneurial intentions and actual participation in entrepreneurial activity. The Total Early-stage Entrepreneurial Activity) rate (13\%) is only slightly more than half the entrepreneurial intentions rate (22\%). (GEM, 2012). According to the GEDI index, Latvians seem to be particularly weak in opportunity perception and recognition and non-fear of failure (despite the positive trend for both of these indicators observed in 2012) (GEDI, 2013).

Table 4.

Profit or loss of commercial companies 2009-2012, mil. eur

Source: Central Statistical Bureau of Latvia 2013. 
SUCCESS

OF A COMPANY

THROUGH VALUE

Deniss Ščeulovs

Vladimirs Šatrevičs

Elīna Gaile-Sarkane
This can be at least a partial explanation for the existing gap. Latvian earlystage enterprises are among those with strong international orientation and high growth ambitions, but the level of innovativeness among Latvian earlystage entrepreneurs remains an area for further improvement. One out of every four early-stage entrepreneurs in Latvia still has "necessity motivation". The rate is higher compared to the EU GEM average (20\%). Moreover, it is still substantially higher compared to the Latvian pre-recession level of necessitydriven entrepreneurship (15\% in 2007). In general a strong cyclical component is evident in Latvian entrepreneurial activity and aspirations. Commercial and Physical Infrastructure and Cultural and Social Norms are areas positively evaluated by national experts. National Policy (Regulations), R\&D Transfer and Internal Market Dynamics are those requiring immediate attention (Krūmiņa et. al., 2012).

The factors that affect the development of entrepreneurship environment can be relatively grouped by their features of impact on environment-macro environment impact factors and micro environment impact factors. These groups, for their part, consist of direct and indirect impact factors. In the article, the authors will not consider the business aptitude of individuals, which has been a very popular object of study and a subject in social studies over the last few years.

\section{Growth of a company}

Each company goes through several stages of development—beginning with the establishment of a company and ending with closing of operations. There are multiple theories and opinions as regards a company's life cycle. One of the founders of the company life cycle theory Levitt distinguishes between four development stages - introduction, growth, maturity, decline (Levitt, 1965). This theory has been used as the basis and developed by a number of scientists. For example, Adizes distinguishes between the following company development stages-Courtship, Infancy, Go-go, Adolescence, Prime, Stability, Aristocracy, Early Bureaucracy, Bureaucracy, Death (Adizes, 2013). Bersin divides the cycle into the stages of formation, rapid growth, maturity, decline, revival or termination of operations (Bersin, 2008). Ahmed believes that a company transforms from an infant company to a transforming or dying company (Ahmed, 2002). Whereas Zahorsky determines seven company development stages: Seed Stage, Start-Up Stage, Growth Stage, Established Stage, Expansion Stage, Decline Stage, Exit Stage (Zahorsky, 2013).

Regardless of the theoretically described number and name of company's life cycle stages, the authors conclude that company development, at the researcher's convenience, consider the second or the Growth stage of company development after a company is established (see Figure 1). It is an important stage to study 
because in this stage, according to the researchers, the company theoretically "has overcome the start-up issues and the business has made it through the toddler years and it is now a child" (Adizes, 2004). Revenues and customers are increasing with many new opportunities and issues. Profits are strong, but competition is surfacing. Demand begins to accelerate and the size of the total market expands rapidly. It might also be called the "Take off Stage" (Levitt, 1965).

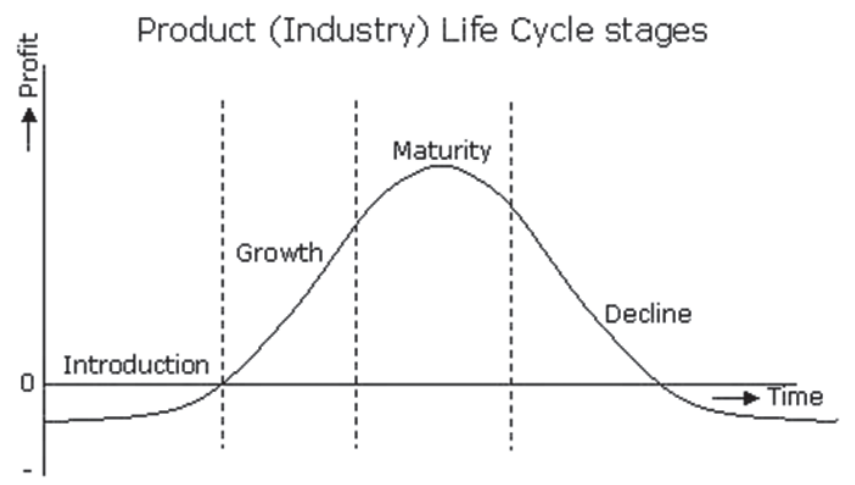

Figure 1. Product (Industry) Life Cycle stages

Source: (Levitt, 1965).

The authors consider the second stage of company development to be very important because during this stage the company grows from "a start-up company" into "a new company" and has already stabilised and is developing rapidly. The organization experiences rapid growth, this growth can be in multiple different directions, founders - over excited by their success - can bring their company to the "brink", many of the new products and ventures being pursued are unprofitable, there are few policies, almost no rules and the founder makes all decisions (Levitt, 1965).

During the growth stage, the company develops the need for arranging processes, control, systematisation, etc. Upon summarizing the case studies performed by the authors, it is concluded that during the growth stage it becomes important for the company to engage in strategic planning, which can help arrange, improve, as well as control processes.

\section{The actual value allocation}

The authors believe that during the growth stage the manager/owner must pay additional attention to the team (since company structure is becoming more solid, for more information flexibility and controllability issues from Adizes, 2013). It is proven also by a number of scientific theories. For instance, Sahlman believes that people are just as important as opportunities and deals (Sahlman, 1999). Timmons 
SUCCESS

OF A COMPANY

THROUGH VALUE

Deniss Ščeulovs

Vladimirs Šatrevičs

Elīna Gaile-Sarkane in his model includes three more important cornerstones, which describe the entrepreneurial process - opportunity, resources and team (Timmons, 1999).

However, there are several fundamental important factor groups' relationships describing a successful entrepreneurial process. Having analysed sources of scientific and business literature, as well as several studies on the topic of success factors affecting entrepreneurship. All of the above shows that manager/ owner will face the "value allocation challenges". These situations are regarded to other stakeholders. Obviously, the complexity of decision-making processes concerning values should be recognized. Together with company development, the communication process that provides a more advanced mechanism for exchanging information with stakeholder providing their interaction as decision-makers starting to appear. The overall result will be the greater input from stakeholders and their support for the decisions that are taken.

Company managers deal with the key issue of identifying the relevant stakeholders, and possibly defining different engagement strategies for different groups. Gardner (Gardner et al., 1986) proposed a classification based on two levels of interests and two levels of power and suggest different engagement strategies for the various groups. Thus managers will "listen" - gather information about stakeholder expectations, requests and concerns. This will bring new "stakeholder participation level" where the directly interested groups become more powerful. Different techniques and tools may be used to engage actors in the process. Selecting the most effective set of techniques of engagement is crucial to the success of the whole process. Not only may inappropriate techniques be ineffective but, in some circumstances, they may create unnecessary barriers (Buysse and Verbeke, 2003).

For instance, a company may provide incentives for its employees to acquire specific human capital, which will increase the employees' productivity and create value for the firm as a whole. The result, however, may be higher pay for the employees, or a reduction of their opportunities and an increase in the cost of switching to a different employer. The same may occur with specific physical or organizational capital; this is not a problem where the capital goods are owned by the company, but it may be a problem if they are owned by the company's suppliers. Similarly, the company may transfer certain more or less explicit risks or costs to other stakeholders. Unions may put pressure on the company in an attempt to capture part of the owners' extraordinary profit; or management may distribute part of the surplus among the employees in order to ensure peaceful industrial relations or obtain other benefits, or simply as a means of transferring value from shareholders to employees.

Above mentioned values will affect the success factors for the model of the entrepreneurial process putting additional accents on its elements (Table 5). 


\section{Description}

Economic extrinsic value (economic value). This is created through collaboration among employees and may be appropriated by either side, as we explained earlier.

Intangible extrinsic value, which is provided by the company, e.g., recognition, some kinds of training, etc. This is not part of the economic value created by a company, although it may be a form of participation in intangible value (e.g., the personal status that comes from working for a highly regarded company).

Psychological intrinsic value, such as satisfaction with the work done. It is not part of the economic rent creation process and cannot be appropriated by the company or other stakeholders, although they may help to create or destroy it.

Intrinsic value that takes the form of operational learning (acquisition of knowledge and capabilities). This is created in the agent, not in the company, but probably with the cooperation of other stakeholders. It is not part of the economic value created by the company, although it may contribute to the creation of economic value in the future. It may also be a (partial) substitute for economic value.

Transcendent value, which consists of evaluative learning. This is generated in the agent himself as a consequence of his own decisions. It alters the agent's ability to assess the consequences of those decisions for himself and for other agents. It is not part of the economic value created by the firm; it cannot be appropriated by the company; and employees create it in themselves, even if they do not seek or expect it.

Value that consists of positive or negative externalities, i.e., value that is felt by agents other than those with whom the relationship or transaction is conducted. For example, relations between employees and the company may result in harm to the environment; or they may generate knowledge that spills over to other people; or they may motivate others to engage in corrupt acts (bad example), etc.

The authors of the article reached a conclusion that based on values recognised and incorporated by the company manager will affect success factors role. The authors chosen Timmons model as a best system at describing and depicting the success factors groups influencing the entrepreneurial process and what they entail (Figure 2).

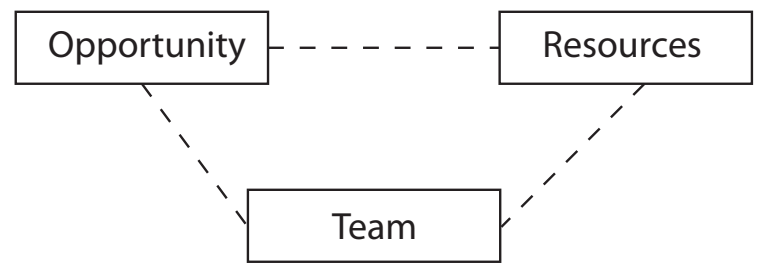

Deniss Ščeulovs Vladimirs Šatrevičs Elīna Gaile-Sarkane

Table 5.

Stakeholders values affecting success factors role in entrepreneurial

process

Source: Argandoña, 2008.

Figure 2. Timmons Model of the entrepreneurial process

Source: (Vyakarnam et al., 2011).

But since, Timmons says: "at the heart of the process (Figure 1) is the opportunity, not all factors are linked to opportunities. Factor group relationship recognition and evaluation is crucial for success. By the authors' opinion, 
SUCCESS

OF A COMPANY

THROUGH VALUE

Deniss Ščeulovs

Vladimirs Šatrevičs

Elīna Gaile-Sarkane important characteristics of factor relationship is provided by stakeholder value allocation principles.

For the entrepreneur, at the early stages of development, maximizing economic value for certain stakeholders is obvious. But it does not guarantee maximum value for each individual stakeholder; it does not even guarantee an efficient and fair distribution of value. Therefore it is needed to consider how value is shared, distributed, appropriated or captured for certain company development stage.

For example resources which are scarce is a tool to exploit opportunities, and here manager will face manager/owner conflict due to economic value allocation problem. At the other hand, the entrepreneurial team is a key ingredient for success, providing additional value for them will build more stable structure.

Good opportunities are that there is as understanding market demand for the product or service because of its value-added properties, and that it will generate money either as a profit or as a means of creating self-sufficiency for not-forprofit organizations. Meanwhile, the team requires determination and persistence, tolerance of risk, ambiguity and uncertainty, creativity, team focus of control, adaptability, opportunity obsession, leadership, communication (Vyakarnam, 2011).

\section{Factors that positively influenced the development of companies}

As a result of study of scientific, business literature, and information, incl., studies of leading economists and specialists, the authors have determined a range of factors that influence successful development of companies (Table 6).

\begin{tabular}{ll}
\hline Factors & Authors \\
\hline $\begin{array}{l}\text { management efficiency, aspects of owner-manager conduct, company's charac- } \\
\text { teristics }\end{array}$ & Peacock, 2000 \\
\hline & $\begin{array}{l}\text { Delmar and } \\
\text { Shane, 2006; } \\
\text { lack of entrepreneurship experience, manager's experience in the specific sec- } \\
\text { tor or market, education level, experience in entrepreneur-ship, reasonability of } \\
\text { the decision to start a business, goal-oriented nature }\end{array}$ \\
$\begin{array}{ll}\text { Kolvereid, } \\
\text { 2005; }\end{array}$ \\
\hline $\begin{array}{l}\text { Gelderen, 2011 } \\
\text { when necessary, power sharing, and managers' experience, insufficient work }\end{array}$ & Mason, 2013 \\
\hline $\begin{array}{l}\text { business model as a positive factor } \\
\text { Osterwalder, } \\
\text { the number of created jobs, attracted investments, value added in a form of } \\
\text { services rendered to clients or in a form of goods (turnover) }\end{array}$ & $\begin{array}{l}\text { Cedere et.al., } \\
2001\end{array}$ \\
\hline
\end{tabular}




\begin{tabular}{|c|c|}
\hline Factors & Authors \\
\hline $\begin{array}{l}\text { dream - entrepreneurs have a vision and the ability to implement their dreams; } \\
\text { decisiveness - they make decisions swiftly, their swiftness is a key factor in } \\
\text { their success; doers - once they decide on a course of action, they implement } \\
\text { it as quickly as possible; determination - they implement their ventures with } \\
\text { total commitment; dedication - they are totally dedicated and work tirelessly; } \\
\text { devotion - entrepreneurs love what they do; details - the entrepreneur must be } \\
\text { on top of the critical details; destiny - they want to be in charge of their own } \\
\text { destiny; dollars - getting rich is not the prime motivator, but the measure of } \\
\text { success; distribute - entrepreneurs distribute ownership of the business with } \\
\text { key employees }\end{array}$ & Bygrave, 1997 \\
\hline $\begin{array}{l}\text { work hard and are driven by intense commitment and determined perseve- } \\
\text { rance; optimistic outlook; strive for integrity; burn with competitive desire to } \\
\text { excel and win; dissatisfied with the status quo and seek opportunities to impro- } \\
\text { ve almost any situation; use failure as a tool for learning; eschew perfection in } \\
\text { favour of effectiveness; believe that they personally can make a difference }\end{array}$ & Timmons, 1999 \\
\hline $\begin{array}{l}\text { the courage to take risks, confidence, and intuition for entrepreneur; foreign } \\
\text { investors' perception (the image thereof is dominated by): sound manage- } \\
\text { ment skills, self-criticism, openness, practical approach, arrogance, lack of } \\
\text { knowledge }\end{array}$ & $\begin{array}{l}\text { Swedbank En- } \\
\text { trepreneurship } \\
\text { Competence } \\
\text { Centre, } 2001\end{array}$ \\
\hline
\end{tabular}

Table 6. Factors that positively influenced the development of companies

\section{Success factors of Latvian companies: "Success code" model}

To find out the factors that affect the success of a start-up company in business, the authors of the article have performed an empirical pre-research with the aim of finding out the factors and conditions affecting the creation of a company, as well as their successful start-up and the transition into the stage of "a new company". The pre-research is based on the survey conducted by IDAL "Success code" (IDAL, 2009). The survey dealt with twelve of the most successful companies in Latvia representing various sectors (creative industry, IT fields, representatives of the production and other fields), with the owners and/or managers whereof in-depth interviews were conducted. The surveyed companies have competitive products, which are sought after in Latvian and foreign markets; stable and growth-oriented financial indices pointing to successful entrepreneurship of the companies.

As a result of the survey, several factors were identified related to the role of generation and development of an idea, clients and communication with them in business processes, the importance of the company's founders and team, etc.

To examine data validity, the authors of the article used a data analysis performed with QDA Miner (QDA Miner, 2013) statistical analysis software. Out of specific factors specific key words could be determined (depending on their 
SUCCESS

OF A COMPANY

THROUGH VALUE

Deniss Ščeulovs

Vladimirs Šatrevičs

Elīna Gaile-Sarkane

Figure 3.

Success factors model affecting entrepreneurial process

Source: the authors' created model based on Timmons Model (Vyakarnam et al., 2011).

Table 7. Factors that positively influenced the development of companies

Source: "Success code" (IDAL, 2009) survey results. weight) in the software during the analysis. According to identified key words, factors were found in the whole text corresponding to these key words. As a result, the factors grouped by the authors of the article were grouped and hierarchically arranged depending on their importance. The factor groups are:

1) the idea (factors related to the idea),

2) the team - people (excluding the manager-founder),

3) the manager-founder,

4) the entrepreneur,

5) clients and the market.

The authors agree to this grouping because in company development it is vitally important to have an idea to begin the business with and to capture the market; the manager (founder), who is able to excite with the idea as well as to convince and lead the team. And the team itself, believing in the product and able to sell it on the market. Finally, a company cannot exist without the clients, their feedback and purchases, but these are external factors and the authors excluded them from the research.

The authors of the article have modelled together success factors obtained as a result of the study, by modifying Timmons Model (Vyakarnam et al., 2011), dividing them into four groups - Entrepreneur, Opportunity, Team and Resources (Figure 3).

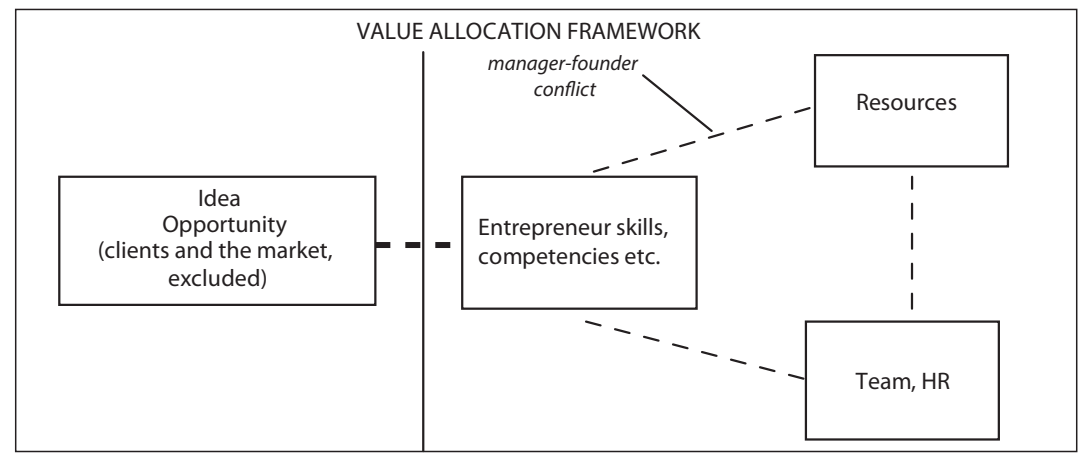

In grouping the factors, the authors of the article would like to maintain that entrepreneurs' competencies play significant role (Table 7).

\begin{tabular}{ll}
\hline Factor group & Number of factors \\
\hline Idea, opportunity (clients and the market) & 23 \\
\hline Entrepreneur & 40 \\
\hline Team & 28 \\
\hline Resources & 6
\end{tabular}


It could be explained with the fact that all companies, regardless of their considerable achievements on markets, are recently established. During the startup stage, it is the idea that is the most important, which is then materialized into a product. But lately, during growth stage, other factor becoming more important. The factor group "Opportunities" include factors that are related to the idea, a product, market opportunities, etc. Furthermore, all companies are SMEs, in which the team and team-related aspects play an important role. Companies are aware of resource importance and necessity, but due to the fact that they are in the development stage, precaution is observed when attracting bigger financial resources-companies choose to rely on their own potential during this development stage. The same applies also to other resources.

The article authors point to that resources and financing sources are necessary, which, as a result of analysis, were not estimated as important.

As a limitation, the authors underline that some factors explain entrepreneur and idea relationship (e.g. engaging rational and intuitive thinking in the process of creating an idea) so they could be interpreted as a process characteristics. Therefore, the authors will perform further factor analyses in the upcoming studies to group and classify success factors model affecting long-term development of business.

\section{Conclusions}

The economy of Latvia, just like other EU countries, is based on SMEs. The number of SMEs increases in Latvia each year. Moreover, the financial indices of SMEs over the last few years have improved. All of these facts point to economic recovery after the global crisis.

As start-ups develop, there are several factors that determine their successful operations. Several scientists and specialists, when performing studies about business success, point to the importance of the company stakeholders' role, characteristics, abilities, knowledge, etc., their mandatory participation in all business processes, in particular during the initial stages. The team also has an important role and only the founder can form that team. Team members must be creative, flexible, and competent, because start-ups have very limited resources, including human resources.

The empirical pre-research survey conducted by the authors allowed identifying several factors affecting a company's long-time development. According to an analysis performed by QDA Miner, the factors were divided into four groups. The authors of the article performed factor grouping based on the Timmons model. The authors point to that the factors described and grouped in this article will serve as the grounds for further studies, in which the authors are to perform factor classification.

The named factors are mutually related and must be considered as a whole and not separately. 
SUCCESS OF A COMPANY THROUGH VALUE

Deniss Ščeulovs Vladimirs Šatrevičs Elīna Gaile-Sarkane
The thesis set forth by the authors is proven with the study on success of Latvian companies, determined by various factors identified by the authors of the article. This article is just the first step in successful company development researching filed. Others steps will be developed and described in next authors' scientific researchers and articles.

\section{References}

Ahmed, A. M. (2002), "Virtual integrated performance measurement", International Journal of Quality \& Reliability Management, Vol. 19 No. 4, pp. 414-441. DOI: http://dx.doi.org/ 10.1108/02656710210421580

Adizes, I. (2013), "Understanding the corporate life cycle", available at: http://www. adizes.com (accessed 03 January 2014).

Adizes, I. (2004), "Managing corporate life cycles", $2^{\text {nd }}$ Edition, available at: http://www. adizes.com (accessed 04 January 2014).

Argandoña, A. (2008), "Integrating ethics into action theory and organizational theory", Journal of Business Ethics, Vol. 78 No. 3, pp. 435-446.

Bersin, J. (2008), "Make learning part of your business strategy", available at: http:// joshbersin.com/2008/07/31/makelearning-part-of-your-business-strategy/ (accessed 12 January 2014).

Buysse, K., Verbeke, A. (2003), "Proactive environmental strategies: a stakeholder management perspective", Strategic Management Journal, Vol. 24 No. 5, pp. 453-470. DOI: http://dx.doi.org/10.1002/smj.299

Bygrave, W. (1997), The Portable MBA in Entrepreneurship, $2^{\text {nd }}$ edition, John Wiley \& Sons Inc., New York.

Cedere, A., McKelvie. (2001), "A Creative Center and Beyond”, University start-ups in Jonkoping, JIBS Working paper series, Vol. 3 No. 1, pp. 26-28.

Central Statistical Bureau of Latvia, (2015), "Economically active statistical units in Latvia 2009-2012", available at: http://data.csb.gov.lv/Table.aspx?layout=table VieLaout1\&px_tableid=SR0011.px\&px_path=uzreg__Ikgad\%C4\%93jie\%20 statistikas\%20dati_01_skaits\&px_language=en\&px_db=uzreg\&rxid=cdcb978c22b0-416a-aacc-aa650d3e2ce0 (accessed 24 October 2015).

Central Statistical Bureau of Latvia, (2015), "Economically active statistical units in Latvia by size group", available at: http://data.csb.gov.lv/Selection.aspx?px_path=uzreg_ Ikgad\%C4\%93jie\%20statistikas\%20dati_01_skaits\&px_tableid=SR0041.px\&px_ language $=1 v \& p x \_d b=u z r e g \& r x i d=c d c b 978 c-22 b 0-416 a-a a c c-a a 650 d 3 e 2 c e 0$ (accessed 24 October 2015).

Central Statistical Bureau of Latvia, (2014), "Profit or loss of commercial companies 2009-2012, mil. eur.", available at: http://data.csb.gov.lv/Table.aspx? layout $=$ tableViewLayout $1 \&$ px_tableid=UF0020_euro.px\&px_path $=$ ekfin__ Ikgad\%C4\%93jie\%20statistikas\%20dati_Uz\%C5\%86\%C4\%93m\%C4\%93j darb\%C4\%ABbas\%20finanses\&px_language $=$ en\&px_db=ekfin\&rxid=cdcb978c22b0-416a-aacc-aa650d 3e2ce0 (accessed 13 January 2014).

Gardner, J., Rachlin, R., Sweeny, A. (1986), Handbook of strategic planning, Wiley, New York. 
Gelderen, M., Thurik, R., Patel, P. (2011), "Encountered problems and outcome status in nascent entrepreneurship", Journal of small business management, Vol. 49 No. 1, pp. 71-91, available at: http://people.few.eur.nl/thurik/Research/Articles/Encountered\%20problems\% (accessed 12 January 2014).

GEDI Index, (2012), available at: http://www.thegedi.org/research/gedi-index (accessed 15 January 2014).

GEM, (2013), “Global Report”, available at: http://www.gemconsortium.org/docs/3106/ gem-2013-global-report (accessed 15 January 2014).

Krumina, M., Paalzow, A. (2012), "Global Entrepreneurship Monitor”, available at: http://www.biceps.org/assets/docs/gem/GEM_2012.pdf (accessed 13 January 2014).

Levitt, T. (1965), "Exploit the product life cycle", Harvard Business Review, Vol. 43 Nov.-Dec. 1965, pp. 81-94.

LIAA, (2012), "Veiksmes kods", available at: http://www.liaa.gov.lv/veiksmes-kodsuznemeju-stasti-un-atzinas (accessed 13 January 2014).

Mason, M. K. (2105), "What Causes Small Businesses to Fail?", available at: http://www. moyak.com/papers/small-business-failure.html (accessed 15 January 2014).

Osterwalder, A., Balnk, S., Smith, A. (2014), "Success Entrepreneurship", available at: http://www.slideshare.net/Alex.Osterwalder/successfulentrepreneurship-5747012 (accessed 19 January 2014).

Peacock, R. (2000), "Failure and assistance of small firms", Specialist Small Business Consultants, Vol. 20 No. 1, pp. 1-26.

QDA Miner, (2013), available at: http://provalisresearch.com/solutions/ (accessed 11 January 2014).

Register of Enterprises of Latvia, (2013), "New and eliminated companies in Latvija, 2002-2013", available at: http://www.ur.gov.lv/statistika.html?a=1091 (accessed 11 December 2013).

Reinolds, P., Curtin, N. (2011), New business creation, An international overview, Springer, New York.

Sahlman, W. A., Stevenson, H. H., Roberts, M. J., Bhide, A. (1999), “The entrepreneurial venture", $2^{\text {nd }}$ edition, Harvard Business School Press, Vol. 1 No. 1, pp.174-175.

SBA Office of Advocacy, (2012), "Frequently Asked Questions about Small Business", available at: http://www.sba.gov/sites/default/files/FAQ_Sept_2012.pdf (accessed 11 January 2014).

SBA Facts, (2012), available at: http://ec.europa.eu/enterprise/policies/sme/facts-figuresanalysis/performance-review/files/countries-sheets/2012/latvia_lv.pdf (accessed 13 January 2014).

Timmons, J. (1999), New Venture Creation: Entrepreneurship for the $21^{\text {st }}$ Century, $5^{\text {th }}$ Edition, London: McGraw Hill, London.

Uzṇēmējdarbības kompetences centrs, (2012), Survey: "Attieksme pret uzṇēmējdarbības uzsākšanu", available at: http://www.manambiznesam.lv/lv/2012/03/19/attieksmepret-uznemejdarbibas-uzsaksanu (accessed 11 January 2014).

Vyakarnam, S., Hartman, N. (2011), Unlocking the Entrepriser Inside!, Singapore: World Scientific Publishing Co. Pte. Ltd., Singapore.

Zahorsky, D. (2015), "Find Your Business Life Cycle", available at: http://sbinformation. about.com/cs/marketing/a/a040603_2.htm (accessed 11 January 2014). 